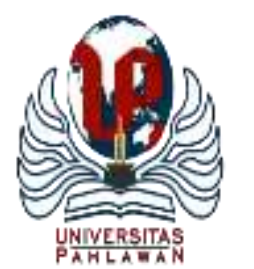

Edukatif : Jurnal Ilmu Pendidikan Volume 4 Nomor 1 Tahun 2022 Halm 1528 - 1535

EDUKATIF: JURNAL ILMU PENDIDIKAN

Research \& Learning in Education

https:/ledukatif.org/index.php/edukatif/index

\title{
Pengaruh Minat Belajar Peserta Didik terhadap Pembelajaran Daring Mata Pelajaran Bahasa Indonesia di Masa Pandemi Covid 19
}

\author{
Hany Uswatun Nisa ${ }^{1 \bowtie}$, Rizki Umi Nurbaeti ${ }^{2}$, Nurchalistiani Budiana ${ }^{3}$ \\ Universitas Muhadi Setiabudi, Indonesia ${ }^{1,2,3}$ \\ E-mail : hanyuswatunnisa@gmail.com ${ }^{1}$, $\underline{\text { rizkiuminurbaeti@gmail.com }}^{2}, \underline{\text { chalistia@gmail.com }}^{3}$
}

\begin{abstract}
Abstrak
Tujuan penelitian ini adalah: (1) Untuk mendeksripsikan seberapa tinggi minat belajar peserta didik dalam Mata Pelajaran Bahasa Indonesia pada pembelajaran daring (2) Untuk mendeskripsikan seberapa tinggi hasil belajar peserta didik dalam Mata Pelajaran Bahasa Indonesia pada pembelajaran daring (3) Mengetahui pengaruh yang signifikan antara minat belajar dengan hasil belajar peserta didik dalam Mata Pelajaran Bahasa Indonesia dalam pembelajaran daring. Penelitian ini merupakan jenis penelitian kuantitatif deskriptif, dengan menggunakan analisis korelasi. Teknik pengumpulan data menggunakan angket yang bersifat tertutup, dengan menggunakan internet sebagai media penyebarannya. Hasil penelitian ini berupa: (1) Minat belajar peserta didik termasuk dalam kategori sedang. Hasilnya menunjukkan bahwa jumlah frekuensi paling banyak yaitu 100 frekuensi, dengan jumlah interval 25,856 $\leq \mathrm{X} \leq 30,284$ dan jumlah prosentase sebanyak 82,644. (2) Hasil belajar peserta didik termasuk dalam kategori sedang. Hasilnya menunjukkan bahwa jumlah frekuensi paling banyak yaitu 99 frekuensi, dengan jumlah interval 12,155 $\leq \mathrm{X} \leq 16,365$ dan jumlah prosentase sebanyak 81,818. (3) Hasil uji korelasi product moment pada variabel X dan Y, menunjukkan rtabel dengan taraf signifikan 0,05 dan jumlah responden sebanyak 121 orang adalah 0,1786. Sehingga dapat disimpulkan bahwa hipotesis yang diajukan (Ha) diterima dan (Ho) ditolak.
\end{abstract}

Kata Kunci: Minat Belajar, Hasil Belajar, Pembelajaran Daring.

\begin{abstract}
The objectives of this study are: (1) To describe how high students' learning interest in Indonesian Language Subjects is in online learning (2) To describe how high students' learning outcomes in Indonesian Language Subjects are in online learning (3) To determine the significant effect between learning interest and student learning outcomes in Indonesian Language Subjects in online learning. This research is a type of descriptive quantitative research, using correlation analysis. The data collection technique uses a closed questionnaire, using the internet as a medium of dissemination. The results of this study are: (1) Students' learning interest is included in the medium category. The results show that the number of frequencies at most is 100 frequencies, with the number of intervals of 25,856 X 30,284 and the number of percentages as much as 82,644. (2) The learning outcomes of students are included in the medium category. The results show that the highest number of frequencies is 99 frequencies, with the number of intervals 12,155X 16,365 and the number of percentages as much as 81,818 . (3) The results of the product moment correlation test on variables $X$ and $Y$, show rtable with a significant level of 0.05 and the number of respondents as many as 121 people is 0.1786 . So it can be concluded that the proposed hypothesis $(\mathrm{Ha})$ is accepted and $(\mathrm{Ho})$ is rejected.
\end{abstract}

Keywords: Learning Interest, Learning Outcomes, Online Learning.

Copyright (c) 2022 Hany Uswatun Nisa, Rizki Umi Nurbaeti, Nurchalistiani Budiana

$\triangle$ Corresponding author

Email : hanyuswatunnisa@gmail.com

DOI : https://doi.org/10.31004/edukatif.v4i1.2110

ISSN 2656-8063 (Media Cetak)

ISSN 2656-8071 (Media Online) 
1529 Pengaruh Minat Belajar Peserta Didik terhadap Pembelajaran Daring Mata Pelajaran Bahasa Indonesia di Masa Pandemi Covid 19- Hany Uswatun Nisa, Rizki Umi Nurbaeti, Nurchalistiani Budiana

DOI: https://doi.org/10.31004/edukatif.v4i1.2110

\section{PENDAHULUAN}

Bahasa yang digunakan oleh bangsa Indonesia adalah bahasa Indonesia, yang telah ditetapkan dalam UUD 1945 pasal 36. Oleh sebab itu pembelajaran bahasa Indonesia diajarkan pada semua jenjang pendidikan, mulai dari Sekolah Dasar sampai dengan Perguruan Tinggi. Hal ini bertujuan untuk meningkatkan kemampuan peserta didik untuk berkomunikasi dalam bahasa Indonesia dengan baik dan benar, baik secara lisan maupun tulis. Tentunya dalam proses pemebalajaran, khususnya dalam mata pelajaran Bahasa Indonesia seorang pendidik pasti menginginkan peserta didik agar mempunyai minat belajar yang tinggi. Sehingga hasil belajar khususnya pada mata pelajaran Bahasa Indonesia bisa sesuai dengan yang diharapkan. (Zanita, 2018).

Minat belajar peserta didik juga sangat berpengaruh terhadap hasil belajar peserta didik. Belajar tanpa minat akan terasa membosankan, walaupun kenyataannya tidak semua belajar peserta didik didorong oleh faktor minatnya sendiri. Ada yang mengembangkan minatnya terhadap materi pelajaran dikarenakan pengaruh dari gurunya, temannya, ataupun orang tuanya. Ada dua faktor yang mempengaruhi minat belajar peserta didik, yaitu faktor internal yang berasal dari dalam diri peserta didik itu sendiri dan faktor eksternal yang berasal dari luar diri peserta didik, misalnya faktor lingkungan dan keluarga (Khairani, 2019).

Baru-baru ini proses belajar mengajar di Indonesia menjadi terganggu (Pendy et al., 2022). Hal ini dikarenakan munculnya virus Corona atau yang lebih dikenal dengan Covid-19 di Indonesia. Untuk mencegah penyebaran Covid-19 yang semakin meluas, maka dilakukan beberapa cara penanggulangannya, salah satunya pemerintah menyarankan untuk melakukan banyak kegiatan dari rumah, termasuk belajar dari rumah (Atmojo \& Nugroho, 2020). Hal ini kemudian direspon baik dengan dikeluarkannya surat edaran Menteri Pendidikan yang meliburkan sekolah sementara. Hampir seluruh sekolah di Indonesia melakukan pembelajaran secara daring dari rumah (Mendikbud, 2020).

Langkah yang diambil dari pemerintah sebagai upaya memutus mata rantai Covid-19 berdampak di berbagai sektor, salah satunya pada bidang pendidikan (Veda et al., 2016). Kebijakan tersebut memberikan dampak pada pendidikan di Indonesia khususnya pada pembelajaran di Sekolah. Peralihan dari pembelajaran secara tatap muka ke pembelajaran daring atau pembelajaran jarak jauh menjadi sesuatu yang baru bagi guru dan peserta didik. Kondisi semacam ini juga berlaku di SMP Negeri 1 Ketanggungan. Walaupun di Kecamatan Ketanggungan Kabupaten Brebes bukan termasuk wilayah pada zona merah, tetapi sebagian besar bahkan seluruh sekolah yang ada di Kecamatan Ketanggungan baik dari tingkat PAUD/TK, SD, SMP, maupun SMA proses pembelajaran saat ini masih dilakukan secara daring.

Menurut salah satu guru SMP Negeri 1 Ketanggungan bagian urusan sarana dan prasarana, Ibu Romafi M.Pd pada wawancara hari Kamis tanggal 2 Desember 2021. Terdapat banyak hal positif yang didapat dari kegiatan belajar yang dilakukan di rumah, contohnya saja kondisi kesehatan yang semakin baik dan orang tua/wali murid dapat mengontrol dan mengawasi anaknya dalam belajar. Jadi orang tua lebih tahu kondisi anak mereka saat belajar Nurpratiwiningsih et al., (2020). Dari beberapa hal positif pada pembelajaran daring yang dilakukan, terdapat juga beberapa hambatan dan tantangan yang harus dihadapi dari proses belajar ini. Salah satunya adalah kurangnya minat belajar peserta didik terhadap materi pelajaran dan kurangnya persiapan guru dalam menghadapi proses belajar di rumah, sehingga mempengaruhi hasil belajar yang kurang optimal dan cenderung menurun (Hamat \& Hassan, 2019).

Penelitian yang berkaitan dengan minat belajar peserta didik pernah dilakukan oleh Sinaga (2017) yang berjudul "Pengaruh Strategi Pembelajaran danMinat Belajar Terhadap Hasil Belajar Bahasa Indonesia" Hasil penelitian diperoleh: (1) Hasil belajar bahasa Indonesia siswa yang belajarkan dengan menggunakan Strategi Pembelajaran Peningkatan Kemampuan Berpikir lebih tinggi dibandingkan dengan hasil belajar bahasa Indonesia siswa yang dibelajarkan dengan menggunakan Strategi Inquiri, (2) Hasil belajar bahasa Indonesia siswa yang memiliki minat belajar tinggi lebih tinggi dibandingkan dengan siswa yang memiliki minat belajar rendah dan (3) Terdapat interaksi antara 
1530 Pengaruh Minat Belajar Peserta Didik terhadap Pembelajaran Daring Mata Pelajaran Bahasa Indonesia di Masa Pandemi Covid 19- Hany Uswatun Nisa, Rizki Umi Nurbaeti, Nurchalistiani Budiana

DOI: https://doi.org/10.31004/edukatif.v4i1.2110

penggunaan strategi pembelajaran dengan minat belajar dalam mempengaruhi hasil belajar bahasa Indonesia. Implikasi dari penelitian ini secara khusus ditujukan kepada guru bahasa Indonesia yaitu dalam penerapan strategi pembelajaran harus diperhatikan karakteristik siswa khususnya minat belajar.

Perbedaan penelitian tersebut dengan penelitian yang peneliti lakukan yaitu: Metode penelitian yang digunakan adalah dengan metode quasi eksperimen. Sedangkan metode yang digunakan peneliti dalam penelitian ini menggunakan metode survey. Teknik analisis data menggunakan teknik perhitungan anava. Sedangkan penelitian yang peneliti gunakan menggunakan teknik analisis data korelasi product moment, uji validitas, uji reliabilitas, dan kategorisasi.

Intrumen penelitian yang digunakan adalah dengan menggunakan strategi pembelajaran langsung yang dilakukan pada siswa. Sedangkan pada penelitian yang peneliti lakukan menggunakan instrumen penelitian angket atau kuesioner.

Minat merupakan salah satu faktor psikis yang membantu dan mendorong individu dalam memberi stimulus pada suatu kegiatan yang dilaksanakan untuk mencapai tujuan yang hendak dicapai. Lebih lanjut, menurut Huda (2017) minat atau interest adalah kecenderungan dan kegairahan yang tinggi atau keinginan yang besar terhadap sesuatu. Minat ini erat kaitannya dengan perasaan terutama perasaan senang, karena itu dapat dikatakan minat itu terjadi karena sikap senang kepada sesuatu. Orang yang berminat kepada sesuatu berarti sikapnya senang kepada sesuatu itu.

Ada dua faktor yang mempengaruhi minat dalam belajar menurut Dewi, (2020) yaitu faktor internal dan eksternal. Faktor internal adalah suatu hal yang dapat membuat peserta didik berminat dalam belajar, yang berasal dari dalam diri peserta didik itu sendiri. Faktor internal tersebut diantaranya yaitu perhatian,keingintahuan, dan motivasi (Pratiwi \& Ubaedillah, 2021). Sedangkan faktor eksternal adalah suatu hal yang dapat membuat peserta didik berminat dalam belajar, yang berasal luar diri peserta didik.Faktor eksternal tersebut diantaranya yaitu dorongan semamgat dari orang tua, dorongan semangat dari guru, tersedianya sarana dan prasarana atau fasilitas belajar yang mencukupi, dan keadaan lingkungan (Sugianto \& Ulfah, 2020).

Hasil belajar merupakan kemampuan yang di dapat dari suatu kegiatan pembelajaran yang dilakukan oleh peserta didik yang dapat menghasilkan peserta didik produktif, kreatif, serta inovatif melalui satu kesatuan penguasaan baik sikap, keterampilan, maupun pengetahuan. Lebih lanjut, Ubaedillah \& Pratiwi (2021) hasil belajar merupakan hal yang dapat dipandang dari dua sisi, yaitu sisi peserta didik dan sisi guru. Dari sisi peserta didik, hasil belajar merupakan tingkat perkembangan mental yang lebih baik bila dibandingkan pada saat sebelum belajar, dan untuk dari sisi guru hasil belajar merupakan suatu kompetensi yang diharapkan agar peserta didik dapat memperoleh suatu pencapaian yang baik dalam suatu pembelajaran (Prihartanta, 2015).

\section{METODE PENELITIAN}

Penelitian ini merupakan jenis penelitian kuantitatif deskriptif. Penelitian kuantitatif deskriptif merupakan sebuah penelitian yang mempunyai tujuan untuk memberikan sebuah penjelasan terhadap sebuah kondisi atau bisa karena berbagai variabel yang timbul di masyarakat yang menjadi objek penelitian berdasarkan pada fenomena yang terjadi, kemudian data yang didapat diolah dengan menggunakan aplikasi SPSS Arifin (2020). Jenis metode kuantitatif deskriptif yang digunakan dalam penelitian ini adalah metode survey. Survey atau lebih lengkapnya self-administered survey adalah metode pengumpulan data primer dengan memberikan pertanyaan-pertanyaan lepada responden individu. Dengan tujuan untuk mengumpulkan informasi dari kelompok yang mewakili sebuah populasi. Jenis metode survey yang peneliti ambil adalah metode survey penjelasan atau eksplanatori, yaitu menekankan pada pada pencarian hubungan kausalitas atau sebab akibat antara variabel-variabel yang diteliti. 
1531 Pengaruh Minat Belajar Peserta Didik terhadap Pembelajaran Daring Mata Pelajaran Bahasa Indonesia di Masa Pandemi Covid 19- Hany Uswatun Nisa, Rizki Umi Nurbaeti, Nurchalistiani Budiana

DOI: https://doi.org/10.31004/edukatif.v4i1.2110

Teknik pengumpulan data dalam penelitian ini menggunakan angket atau kuesioner yang bersifat tertutup, atau dengan menggunakan internet sebagai media penyebarannya (Creswell, 2014). Hal ini dilakukan karena situasi dan kondisi yang masih pandemi Covid-19, dimana kondisi peserta didik masih belajar di rumah masing-masing. Populasi dalam penelitian ini adalah seluruh peserta didik kelas VIII SMP Negeri 1 Ketanggungan tahun ajaran 2021/2022 yang berjumlah sembilan kelas. Sedangkan sampel pada penelitian ini peneliti mengambil empat kelas, yaitu kelas VIII A, B, C, dan D sebagai sampel penelitian dari seluruh populasi yang berjumlah sembilan kelas.

Teknik analisis data pada penelitian ini menggunakan Uji Validitas, Uji Reliabilitas, dan Uji Korelasi Product Moment. Uji Validitas dalam penelitian ini digunakan untuk menghitung korelasi antara masingmasing pernyataan dengan skor total adalah dengan menggunakan rumus korelasi product moment. Uji Reliabilitas merujuk pada pengertian apakah sebuah instrumen dapat mengukur sesuatu yang diukur secara konsisten dari waktu ke waktu. Jadi, kata kunci untuk syarat kualifikasi suatu instrumen pengukur adalah konsistensi, kejaegan, atau tidak berubah-ubah. Korelasi Product Moment pada penelitian digunakan untuk mengetahui hubungan yang signifikan antara minat belajar dengan hasil belajar peserta didik pada Mata Pelajaran Bahasa Indonesia dalam pembelajaran daring di masa pandemi Covid-19 (Ariyanti, 2020).

\section{HASIL DAN PEMBAHASAN PENELITIAN}

Variabel penelitian adalah suatu atribut sifat atau nilai dari orang, obyek atau kegiatan yang mempunyai variasi tertentu yang ditetapkan oleh peneliti untuk dipelajari dan kemudian ditarik kesimpulannya. Terdapat dua variabel dalam penelitian ini, yaitu variabel $X$ atau minat belajar peserta didik dalam mata pelajaran Bahasa Indonesia pada pembelajaran daring di masa pandemi Covid-19 dan variabel Y atau hasil belajar peserta didik dalam mata pelajaran Bahasa Indonesia pada pembelajaran daring di masa pandemi Covid-19. Teknik pengumpulan data dalam penelitian ini menggunakan angket atau kuesioner dengan jumah soal 15 pertanyaan. Yang sebelumnya angket tersebut sudah divalidasi oleh validator. Adapun hasil deskrisi data yang diperoleh dapat dijelaskan sebagai berikut :

\section{Variabel X (Minat Belajar Peserta Didik dalam Pembelajaran Daring)}

a. Uji Validitas

Tabel 1. Hasil Uji Validitas Variabel X

\begin{tabular}{clcc}
\hline \multirow{2}{*}{ NO } & \multicolumn{3}{c}{ Uji Validitas } \\
\cline { 2 - 4 } & rhitung & rtabel & Keterangan \\
\hline 1. & 0,237 & 0,1786 & Valid \\
\hline 2. & 0,230 & 0,1786 & Valid \\
\hline 3. & 0,035 & 0,1786 & Tidak Valid \\
\hline 4. & 0,526 & 0,1786 & Valid \\
\hline 5. & 0,512 & 0,1786 & Valid \\
\hline 6. & 0,571 & 0,1786 & Valid \\
\hline 7. & 0,494 & 0,1786 & Valid \\
\hline 8. & 0,098 & 0,1786 & Tidak Valid \\
\hline 9. & 0,249 & 0,1786 & Valid \\
\hline 10. & 0,350 & 0,1786 & Valid \\
\hline
\end{tabular}

Berdasarkan hasil uji validitas instrumen pada variabel $\mathrm{X}$ atau minat belajar peserta didik dalam mata pelajaran Bahasa Indonesia pada pembelajaran daring di masa pandemi Covid-19, dapat di ketahui bahwa $\mathrm{r}_{\text {tabel }}$ pada taraf signifikan 0,05 dengan jumah responden sebanyak 121 orang adalah 0,1786. Sedangkan untuk 
1532 Pengaruh Minat Belajar Peserta Didik terhadap Pembelajaran Daring Mata Pelajaran Bahasa Indonesia di Masa Pandemi Covid 19- Hany Uswatun Nisa, Rizki Umi Nurbaeti, Nurchalistiani Budiana

DOI: https://doi.org/10.31004/edukatif.v4i1.2110

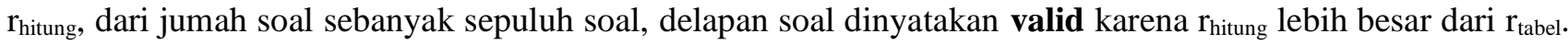
Dan dua soal yaitu soal nomor tiga dan delapan dinyatakan tidak valid, karena $r_{\text {hitung }}$ lebih kecil dari $r_{\text {tabel }}$ dengan taraf signifikannya adalah $\mathbf{0 , 0 3 5}$ dan $\mathbf{0 , 0 9 8}$.

Berdasarkan penjelasan dari hasil diatas, dapat disimpulkan bahwa uji validitas pada instrumen penekitian variabel $X$ dapat dinyatakan valid dan bisa digunakan untuk pengumpulan data tentang minat belajar. Hal ini karena dari sepuluh soal, hanya dua soal yang $r_{\text {hitung }}$ lebih kecil dari $r_{\text {tabel. }}$

b. Uji Reliabilitas

Tabel 2. Hasil Uji Reliabilitas Variabel X

\begin{tabular}{clcc}
\hline NO & \multicolumn{3}{c}{ Uji Reliabilitas } \\
\cline { 2 - 4 } & rhitung & rtabel & Keterangan \\
\hline 1. & 0,657 & 0,1786 & Reliabel \\
\hline 2. & 0,701 & 0,1786 & Reliabel \\
\hline 3. & 0,605 & 0,1786 & Reliabel \\
\hline 4. & 0,623 & 0,1786 & Reliabel \\
\hline 5. & 0,621 & 0,1786 & Reliabel \\
\hline 6. & 0,628 & 0,1786 & Reliabel \\
\hline 7. & 0,651 & 0,1786 & Reliabel \\
\hline 8 & 0,650 & 0,1786 & Reliabel \\
\hline
\end{tabular}

Berdasarkan hasil uji reliabilitas instrumen pada variabel $\mathrm{X}$ atau minat belajar peserta didik dalam mata pelajaran Bahasa Indonesia pada pembelajaran daring di masa pandemi Covid-19, dapat di ketahui bahwa $\mathrm{r}_{\text {tabel }}$ pada taraf signifikan $\mathbf{0 , 0 5}$ dengan jumah responden sebanyak 121 orang adalah 0,1786. Sedangkan untuk $\mathrm{r}_{\text {hitung }}$ adalah sebesar $\mathbf{0 , 6 6 2}$, yang artinya $\mathrm{r}_{\text {hitung }}(\mathbf{0 . 6 6 2}) \geq \mathrm{r}_{\text {tabel }}(\mathbf{0 , 1 7 8 6 )}$. Sehingga dari jumah total soal sebanyak sepuluh soal, dua soal tidak dimasukan dalam perhitungan uji reliablitias karena saat uji validitas kedua soal tersebut tidak valid, yakni soal nomor dua dan delapan. Sehingga dari delapam soal tersebut dapat dinyatakan reliabel.

2. Variabel Y (Hasil Belajar Peserta Didik dalam Pembelajaran Daring)

a. Uji Validitas

Tabel 3. Hasil Uji Validitas Variabel Y

\begin{tabular}{clcc}
\hline NO & \multicolumn{3}{c}{ Uji Validitas } \\
\cline { 2 - 4 } & rhitung & rtabel & Keterangan \\
\hline 1. & 0,595 & 0,1786 & Valid \\
\hline 2. & 0,580 & 0,1786 & Valid \\
\hline 3. & 0,642 & 0,1786 & Valid \\
\hline 4. & 0,689 & 0,1786 & Valid \\
\hline 5. & 0,461 & 0,1786 & Valid
\end{tabular}

Berdasarkan hasil uji validitas instrumen pada variabel $\mathrm{Y}$ atau atau hasil belajar peserta didik dalam mata pelajaran Bahasa Indonesia pada pembelajaran daring di masa pandemi Covid-19 di atas, dapat diketahui bahwa $r_{\text {tabel }}$ pada taraf signifikan $\mathbf{0 , 0 5}$ dengan jumah responden sebanyak 121 orang adalah $\mathbf{0 , 1 7 8 6}$.

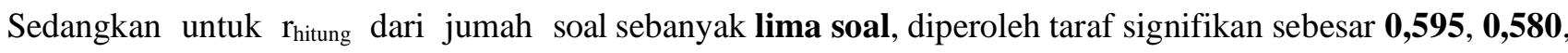
$\mathbf{0 , 6 4 2}, \mathbf{0 , 6 8 9}, \mathbf{0 , 4 6 1}$, dan dapat dinyatakan semuanya valid. Hal ini dibuktikan dengan $\mathbf{r}_{\text {hitung }} \geq \mathbf{r}_{\text {tabel }}$. 
1533 Pengaruh Minat Belajar Peserta Didik terhadap Pembelajaran Daring Mata Pelajaran Bahasa Indonesia di Masa Pandemi Covid 19- Hany Uswatun Nisa, Rizki Umi Nurbaeti, Nurchalistiani Budiana

DOI: https://doi.org/10.31004/edukatif.v4i1.2110

Berdasarkan penjelasan diatas, dapat disimpulkan bahwa uji validitas pada instrumen penekitian variabel $\mathrm{Y}$ dapat dinyatakan valid dan bisa digunakan untuk pengumpulan data tentang minat belajar.

b. Uji Reliabilitas

Tabel 4. Hasil Uji Reliabilitas Variabel Y

\begin{tabular}{llll}
\hline NO & \multicolumn{3}{c}{ Uji Reliabilitas } \\
\cline { 2 - 4 } & rhitung & rtabel & Keterangan \\
\hline 1. & 0,699 & 0,1786 & Reliabel \\
\hline 2. & 0,722 & 0,1786 & Reliabel \\
\hline 3. & 0,712 & 0,1786 & Reliabel \\
\hline 4. & 0,694 & 0,1786 & Reliabel \\
\hline 5. & 0,744 & 0,1786 & Reliabel \\
\hline
\end{tabular}

Berdasarkan hasil uji reliabilitas instrumen pada variabel $\mathrm{Y}$, dapat diketahui bahwa $\mathrm{r}_{\text {tabel }}$ pada taraf signifikan 0,05 dengan jumah responden sebanyak 121 orang adalah $\mathbf{0 , 1 7 8 6}$. Sedangkan untuk $r_{\text {hitung }}$ adalah sebesar $\mathbf{0 , 7 4 5}$, yang artinya $r_{\text {hitung }}(\mathbf{0 , 7 4 5}) \geq r_{\text {tabel }}(\mathbf{0 , 1 7 8 6})$. Sehingga dari jumah soal sebanyak lima soal dapat dinyatakan reliabel.

3. Kategorisasi

Tabel 5. Standar Pembagian Kategori Variabel X

\begin{tabular}{cccc}
\hline Kategori & Interval & Frekuensi & Prosentase \\
\hline Tinggi & $\mathrm{X}>30,284$ & 15 & 13,396 \\
\hline Sedang & $25,856 \leq \mathrm{X} \leq$ & 100 & 82,644 \\
& 30,284 & & \\
\hline Rendah & $\mathrm{X} \leq 25,856$ & 6 & 4,958 \\
\hline
\end{tabular}

Tabel 6. Standar Pembagian Kategori Variabel Y

\begin{tabular}{cccc}
\hline Kategori & Interval & Frekuensi & Prosentase \\
\hline Tinggi & $\mathrm{X}>16,365$ & 14 & 11,570 \\
\hline Sedang & $12,155 \leq \mathrm{X} \leq$ & 99 & 81,818 \\
& 16,365 & & \\
\hline Rendah & $\mathrm{X} \leq 12,155$ & 8 & 6,611 \\
\hline
\end{tabular}

Berdasarkan hasil penghitungan pembagian kategorisasi diatas, dapat diketahui bahwa variabel $\mathrm{X}$ dan Variabel Y termasuk dalam ketegori sedang. Hal ini dibuktikan dengan jumlah frekuensi terbanyak untuk variabel $X$ adalah 100 dan Y 99. Sedangkan jumlah prosentase terbanyak untuk variabel $X$ adalah 82,644\% dan Y 81,818\%.

Secara umum dalam proses kegiatan belajar mengajar, minat belajar sangat dipelukan untuk menentukan hasil belajar peserta didik. Bagaimanapun sempurnanya metode atau cara mengajar yang digunakan oleh pendidik, namun jika minat belajar siswa kurang, maka kegiatan belajar mengajar antara siswa dan guru tidak akan berjalan sesuai dengan target yang ditentukan. Akhirnya hasil belajar peserta tidak tercapai dengan tujuan yang telah ditentukan. Minat belajar merupakan suatu kecenderungan yang erat kaitannya dengan perasaan individu terutama perasaan senang terhadap sesuatu yang dianggapnya berharga atau sesuai dengan kebutuhan dan memberi kepuasan kepadanya. Sedangkan hasil belajar merupakan penilaian pendidik terhadap peserta didik setelah melakukan kegiatan pembelajaran (Sinaga, 2017). 
1534 Pengaruh Minat Belajar Peserta Didik terhadap Pembelajaran Daring Mata Pelajaran Bahasa Indonesia di Masa Pandemi Covid 19- Hany Uswatun Nisa, Rizki Umi Nurbaeti, Nurchalistiani Budiana

DOI: https://doi.org/10.31004/edukatif.v4i1.2110

Berdasarkan hasil penghitungan pembagian kategorisasi variabel $\mathrm{X}$ (Minat Belajar) dan variabel $\mathrm{Y}$ (Hasil Belajar), dapat diketahui bahwa variabel X dan Variabel Y termasuk dalam ketegori sedang. Hal ini dibuktikan dengan jumlah frekuensi terbanyak untuk variabel $\mathrm{X}$ adalah 100 dan $\mathrm{Y}$ 99. Sedangkan jumlah prosentase terbanyak untuk variabel $X$ adalah $\mathbf{8 2 , 6 4 4 \%}$ dan Y 81,818\%.

Sedangkan berdasarkan hasil uji korelasi product moment pada variabel $\mathrm{X}$ dan $\mathrm{Y}$, dapat diketahui bahwa $r_{\text {tabel }}$ pada taraf signifikan 0,05 dengan jumlah responden sebanyak 121 orang adalah 0,1786. Sedangkan untuk $r_{\text {hitung }}$ adalah sebesar 0,396 , yang artinya $r_{\text {hitung }}(0,396) \geq r_{\text {tabel }}(0,1786)$. Sehingga dapat disimpulkan bahwa hipotesis yang diajukan (Ha) diterima dan (Ho) ditolak, dengan kata lain terdapat pengaruh yang signifikan antara minat belajar dengan hasil belajar peserta didik pada Mata Pelajaran Bahasa Indonesia dalam pembelajaran daring di masa pandemi Covid-19 pada peserta didik kelas VIII di SMP Negeri 1 Ketanggungan tahun ajaran 2021/2022.

\section{KESIMPULAN}

Berdasarkan hasil penelitian dan pembahasan tentang Pengaruh Minat Belajar Peserta Didik Terhadap Hasil Belajar Dalam Mata Pelajaran Bahasa Indonesia Pada Pembelajaran Daring di Masa Pandemi Covid-19 diperoleh Minat belajar peserta didik kelas VIII SMP Negeri 1 Ketanggungan termasuk dalam kategori sedang. Dengan jumlah responden sebanyak 121 peserta didik dan telah dihitung dengan menggunakan rumus kategorisasi. Hasilnya menunjukkan bahwa jumlah frekuensi paling banyak yaitu 100 frekuensi, dengan jumlah interval 25,856 $\leq \mathbf{X} \leq \mathbf{3 0 , 2 8 4}$ dan jumlah prosentase sebanyak 82,644. Hasil belajar peserta didik kelas VIII SMP Negeri 1 Ketanggungan termasuk dalam kategori sedang. Dengan jumlah responden sebanyak 121 peserta didik dan telah dihitung dengan menggunakan rumus kategorisasi. Hasilnya menunjukkan bahwa jumlah frekuensi paling banyak yaitu 99 frekuensi, dengan jumlah interval 12,155 $\leq \mathbf{X} \leq \mathbf{1 6 , 3 6 5}$ dan jumlah prosentase sebanyak 81,818. Hasil uji korelasi Product Moment pada variabel $\mathrm{X}$ dan $\mathrm{Y}$, menunjukkan $\mathrm{r}_{\text {tabel }}$ dengan taraf signifikan $\mathbf{0 , 0 5}$ dan jumlah responden sebanyak 121 orang adalah $\mathbf{0 , 1 7 8 6}$. Sedangkan untuk $\mathrm{r}_{\text {hitung }}$ adalah sebesar $\mathbf{0 , 3 9 6}$, yang artinya $\mathbf{r}_{\text {hitung }}\left(\mathbf{0 , 3 9 6 )} \geq \mathbf{r}_{\text {tabel }}(\mathbf{0 , 1 7 8 6 )}\right.$. Sehingga dapat disimpulkan bahwa hipotesis yang diajukan (Ha) diterima dan (Ho) ditolak, dengan kata lain terdapat pengaruh yang positif dan signifikan antara minat belajar dengan hasil belajar peserta didik pada Mata Pelajaran Bahasa Indonesia dalam pembelajaran daring di masa pandemi Covid-19 pada peserta didik kelas VIII di SMP Negeri 1 Ketanggungan tahun ajaran 2021/2022.

\section{DAFTAR PUSTAKA}

Arifin, Z. (2020). Metodologi Penelitian Pendidikan Education Research Methodology. Stit Al-Hikmah Bumi Agung Way Kanan, 1(1), 1-3.

Ariyanti, A. (2020). Efl Students' Challenges Towards Home Learning Policy During Covid-19 Outbreak. Ijeltal (Indonesian Journal Of English Language Teaching And Applied Linguistics), 5(1), 167. Https://Doi.Org/10.21093/Ijeltal.V5i1.649

Atmojo, A. E. P., \& Nugroho, A. (2020). Efl Classes Must Go Online! Teaching Activities And Challenges During Covid-19 Pandemic In Indonesia. Register Journal, 13(1), 49-76. Https://Doi.Org/10.18326/Rgt.V13i1.49-76

Creswell, J. W. (2014). A Concise Introduction To Mixed Methods Research. Sage Publications.

Dewi, W. A. F. (2020). Dampak Covid-19 Terhadap Implementasi Pembelajaran Daring Di Sekolah Dasar. Edukatif: Jurnal Ilmu Pendidikan, 2(1), 55-61.

Hamat, A., \& Hassan, H. A. (2019). Use Of Social Media For Informal Language Learning By Malaysian University Students. 3l: Language, Linguistics, Literature, 25(4), 68-83. Https://Doi.Org/10.17576/31- 
1535 Pengaruh Minat Belajar Peserta Didik terhadap Pembelajaran Daring Mata Pelajaran Bahasa Indonesia di Masa Pandemi Covid 19- Hany Uswatun Nisa, Rizki Umi Nurbaeti, Nurchalistiani Budiana

DOI: https://doi.org/10.31004/edukatif.v4i1.2110

2019-2504-05

Huda, M. (2017). Model-Model Pengajaran Dan Pembelajaran: Isu-Isu Metodis Dan Paradigmatis.

Khairani, W. (2019). Peran Orangtua Terhadap Penggunaan Media Internet Dalam Perilaku Keagamaan Anak (Studi Pada Keluarga Muslim Di Kelurahan Bandar Jaya Barat Kecamatan Terbanggi Besar). Uin Raden Intan Lampung.

Mendikbud. (2020). Surat Edaran Nomor 4 Tahun 2020 Tentang Pelaksanaan Kebijakan Pendidikan Dalam Masa Darurat Penyebaran Coronavirus Disease (Covid-19).

Nurpratiwiningsih, L., Arifianto, T., Qosid, W., \& Ubaedillah, U. (2020). Menumbuhkan Sikap Sadar Lingkungan Bagi Anak Usia Sekolah Dasar. Jamu : Jurnal Abdi Masyarakat Umus, 1(1), 34-41.

Pendy, A., Suryani, L., \& Mbagho, H. M. (2022). Edukatif: Jurnal Ilmu Pendidikan Analisis Keefektifan Pembelajaran Online Di Masa Pandemi Covid-19 Pada Mahasiswa Pendidikan Matematika. 4(1), 1927.

Pratiwi, D. I., \& Ubaedillah, U. (2021). Digital Vocabulary Class In English For Railway Mechanical. Teaching English With Technology, 21(August), 67-88. Http://Www.Tewtjournal.Org

Prihartanta, W. (2015). Teori-Teori Motivasi. Jurnal Adabiya, Tahun 2015, Vol. 1 No.(83), 1-11. Https://Www.Academia.Com

Sinaga, R. (2017). Pengaruh Strategi Pembelajaran Dan Minat Belajar Terhadap Hasil Belajar Bahasa Indonesia. Jurnal Teknologi Pendidikan, 10(1), 33-43.

Sugianto, A., \& Ulfah, N. (2020). Construing The Challenges And Opportunities Of Intercultural Language Teaching Amid Covid-19 Pandemic: English Teachers' Voices. Journal Of English Language Teaching And Linguistics, 5(3), 363. Https://Doi.Org/10.21462/Jeltl.V5i3.454

Ubaedillah, U., \& Pratiwi, D. I. (2021). Utilization Of Information Technology During The Covid-19 Pandemic: Student's Perception Of Online Lectures. Edukatif: Jurnal Ilmu Pendidikan, 3(2), 447-455. Https://Doi.Org/10.31004/Edukatif.V3i2.320

Veda, S., Issue, S., Dhanya, G., \& Veda, S. (2016). Influence Of Social Media On English Language Learning. Journal Of English Language And Literature, 3(1), 105-110.

Zanita, E. (2018). Pengaruh Lingkungan Belajar Sekolah Dan Motivasi Belajar Terhadap Kemandirian Belajar Pendidikan Agama Islam Siswa Sd Negeri 14 Bengkulu Selatan Erlina. Jurnal Pendidikan, 3(1), 0-10. 